\title{
La Révolution française : la guerre et la frontière, sous la direction de M. Cubells, Paris, Éditions du CTHS, 2000, 527 pages, $300 \mathrm{~F}$.
}

Jean-Paul Bertaud

\section{(2) OpenEdition}

Édition électronique

URL : https://journals.openedition.org/ahrf/1174

DOI : $10.4000 /$ ahrf. 1174

ISSN : $1952-403 X$

\section{Éditeur :}

Armand Colin, Société des études robespierristes

\section{Édition imprimée}

Date de publication : 1 décembre 2001

Pagination : 194-195

ISSN : 0003-4436

\section{Référence électronique}

Jean-Paul Bertaud, «La Révolution française : la guerre et la frontière, sous la direction de M. Cubells, Paris, Éditions du CTHS, 2000, 527 pages, 300 F. », Annales historiques de la Révolution française [En ligne], 326 | octobre- décembre 2001, mis en ligne le 10 mars 2008, consulté le 23 avril 2022. URL : http://journals.openedition.org/ahrf/1174 ; DOI : https://doi.org/10.4000/ahrf.1174

Ce document a été généré automatiquement le 23 avril 2022.

Tous droits réservés 


\title{
La Révolution française : la guerre et la frontière, sous la direction de M. Cubells, Paris, Éditions du CTHS, 2000, 527 pages, $300 \mathrm{~F}$.
}

\author{
Jean-Paul Bertaud
}

1 Le volume rassemble les communications présentées aux $119^{\mathrm{e}}$ et $121^{\mathrm{e}}$ Congrès nationaux des sociétés historiques et scientifiques (Amiens et Nice, 1994 et 1996). Des frontières du sud-est aux plaines du nord, des villes portuaires méridionales aux frontières avec la Suisse et le Piémont, la mobilisation humaine, matérielle et morale de la France en guerre sous la Révolution et l'Empire est d'abord présentée. L'étude de la défense nationale riche d'enseignements sur l'effort consenti notamment en Normandie, en Picardie et en Alsace s'accompagne d'une série d'enquêtes sur la guerre elle-même : guerre révolutionnaire, guerre «subversive » de l'ordre établi, guerre de propagande et aussi guerre d'expansion et de domination contre laquelle réagissent les populations. D'autres contributions apportent un éclairage particulièrement neuf sur les images de la guerre fournies par les voyageurs ou par les géographes, sur les discours tenus sur la guerre et sur le droit des gens par les diplomates, par les députés de la Première République ou par Bonaparte dont les proclamations sont revisitées par une étude informatisée. Un ouvrage qui enrichit donc l'histoire dite «militaire » qui s'avère être ici, comme il se doit, une histoire globale. 